\title{
Synchronous Locally Advanced Rectal Cancer with Clinical Complete Remission and Important Downstaging after Neoadjuvant Radiochemotherapy - Personalised Therapeutic Approach
}

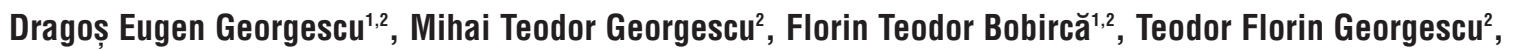 \\ Horia Doran ${ }^{1,2}$, Traian Pătrașcu ${ }^{1,2}$ \\ "I. Juvara” Surgical Department, “Dr. I. Cantacuzino" Clinical Hospital, Bucharest, Romania \\ "Carol Davila" University of Medicine and Pharmacy, Bucharest, Romania
}

Corresponding author:

Horia Doran, MD

Associate Professor of General Surgery

"Dr. I. Cantacuzino" Clinical Hospital

5-7 Ion Movila str., sect.2, Bucharest,

Romania

E-mail: doranh2003@yahoo.com

\section{Rezumat \\ Cancer rectal sincron avansat cu remisie clinică completă, respectiv downstaging important după radiochimioterapie neoadjuvantă - atitudine terapeutică personalizată}

Introducere: În cazul pacienților care obțin un răspuns bun după terapie neoadjuvantă, cu downstaging important, sau chiar remisie completă, practica curentă este de a efectua secvența chirurgicală în funcție de evaluarea preterapeutică. În literatură sunt descrise mai multe abordări posibile pentru pacienții cu răspuns bun după terapie neoadjuvantă, de la exicize endoscopică transanală până la "wait and see". Totuşi, nu există un consens internațional, iar abordările terapeutice care exclud chirurgia nu sunt susținute de studii clinice randomizate.

Prezentare de caz: Este prezentat cazul unui pacient în vârstă de 63 de ani, care este investigat şi diagnosticat cu neoplasm rectal sincron, la nivelul rectului inferior, invaziv în regiunea perianală şi la nivelul rectului mediu, întins axial între 8 şi $14 \mathrm{~cm}$, stadializarea preterapeutică fiind cT4N2M0. Comisia oncologică decide radiochimioterapie neoadjuvantă. La reevaluare postteraputică se constată remisia completă a formațiunii rectale inferioare şi leziune ulcerativ infiltrativă remanentă la nivelul rectului mediu. Pacientul refuză în mod categoric colostomia, asumându-şi riscul de recidivă şi solicitând o intervenție chirugicală cu anastomoză. Se practică o rezecție rectală joasă TME cu anastomoza colo-rectală 
mecanică şi ileostomie de protecție, evoluția postoperatorie fiind favorabilă.

Concluzii: Deşi intervenția chirurgicală radicală ar fi constat într-o rezecție abdomino-perineală, opțiunea pacientului de a refuza colostomia a impus o intervenție radicală doar pentru tumora cranială. Formațiunea tumorală rectală inferioară, remisă complet după terapie neoadjuvantă a fost supusă unei abordări de tip "wait and see".

Cuvinte cheie: rect, cancer, sincron, remisie completă, terapie neoadjuvantă, anastomoză

\begin{abstract}
Introduction: The current practice for patients with good response, important downstaging or complete remission after preoperative chemoradiation, is to perform surgery on the basis of initial pretherapeutical staging. In literature, varying approaches, like transanal endoscopic microsurgery and even "wait and see", are described for patients with good response after chemoradiation. However, considering the present level of available evidence, the wide-spread adoption of a "watch and wait" policy in those achieving a complete clinical remission cannot be justified.

Case report: It is presented the case of a 63 years old patient, investigated and diagnosed with synchronous rectal cancer, inferior rectal cancer invading the perianal region and medium rectal cancer, located between 8 and $14 \mathrm{~cm}$ from the anal verge, pretheraputically staged cT4N2M0. The oncological board decides neoadjuvant radiochemotherapy. Restaging shows complete remission of inferior rectal tumor and ulcerative infiltrative remnant lesion in the medium rectum. The patient firmly declines colostomy, assuming recurrence risks. A TME low rectal resection with colorectal mechanical anastomosis is performed, postoperative evolution being favorable.

Conclusions: Although, the radical surgery to be done would have been an abdomino-perineal resection, the patient's option to decline the colostomy imposed a radical intervention just for the proximal tumor. The inferior rectal tumor, with complete remission after neoadjuvant therapy was submitted to "wait and see" approach.
\end{abstract}

Key words: rectum, cancer, complete remission, neoadjuvant therapy, anastomosis

\section{Introduction}

Neoadjuvant radiochemotherapy became standard treatment for locally advanced rectal cancer (1). Significant tumor downstaging can be achieved and up to $25 \%$ will obtain a pathological complete response (pCR) $(2,3)$. In those who do achieve a good response to chemoradiation and in whom there is tumor downstaging or even complete remission, it is our practice to surgically treat patients based on their initial staging (4). In literature, varying approaches, like transanal endoscopic microsurgery and even "wait and see", are described for patients with good response after chemoradiation. However, it seems that there is no widespread consensus amongst colorectal surgeons regarding the definition of a complete clinical remission (cCR) (5), and therapeutic approaches that exclude surgery are not sustained by randomised clinical trials.

\section{Case Report}

It is presented the case of a 63 years old patient, occasional smoker, without significant clinical antecedents, who is submitted to a medical care unit for rectal bleeding and anal pain. At clinical examination a perianal tumor is found, a biopsy is taken, the result showing intestinal adenocarcinoma (Fig. 1). Digital rectal examination describes rough rectal tumor located endoanally, $1.5 \mathrm{~cm}$ in diameter. Tumoral markers results are CA 19.9 = $8 \mathrm{U} / \mathrm{L}$; 


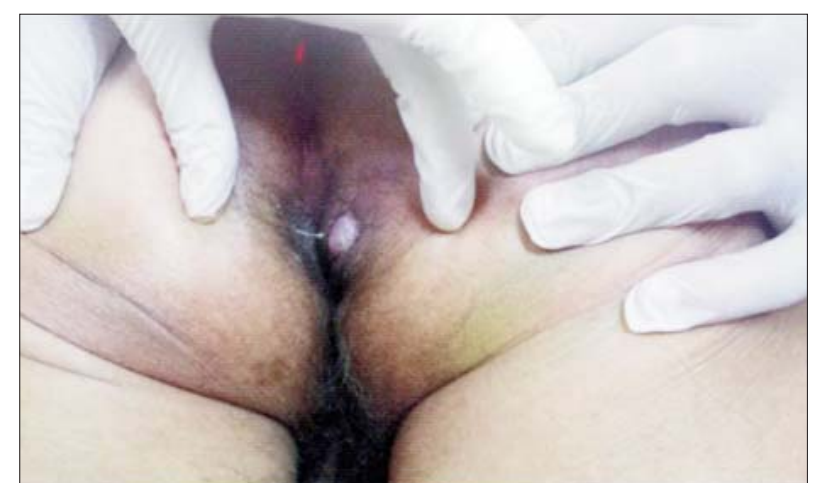

Figure 1. Perianal extension of rectal tumor

$\mathrm{CEA}=31.83 \mathrm{ng} / \mathrm{mL}$. A colonoscopy/rectoscopy, a thorax and abdomen $\mathrm{CT}$ scan and a pelvis MRI are recommended.

A complete colonoscopy is performed and at lower rectum, immediately after the anal canal, with good visualisation through retroflexion, an $1.5 \mathrm{~cm}$ protrusive tumoral area is described. In rest, the rectal ampulla is free. At medium rectum level, above the inferior Houston's valve, with axial extension between 8 and 14 $\mathrm{cm}$ - an ulcero-vegetant, friable, bleeding, voluminous tumor, occupies $70 \%$ circumferential the lumena, largely stenosing, with typical aspect of adenocarcinoma. At sigmoid colon level, $35 \mathrm{~cm}$ from external anal orifice, 2 small grouped hyperplastic polyps, approximately 4 $\mathrm{mm}$ each, benign aspect, without signification in actual context. The rest of sigmoid, descendent, transverse and ascendent colon, the ileocecal valve and cecum without lesions. The thorax-abdomen-pelvis CT scan and the pelvis MRI describe the anal tumor invading external sphincter, parietal rectal tumoral thickening (Fig. 2) and pelvic lymph nodes, without hepatic or peritoneal metastases, without iliac lymph nodes, the patient being staged cT4N2M0.

The oncological board decides neoadjuvant radiochemoterapy, the proposed therapeutical strategy being: 2 series of chemotherapy concomitant radiochemotherapy - surgery chemotherapy.

\section{Neoadjuvant Chemoradiotherapy}

Initially the patient received 2 cycles of

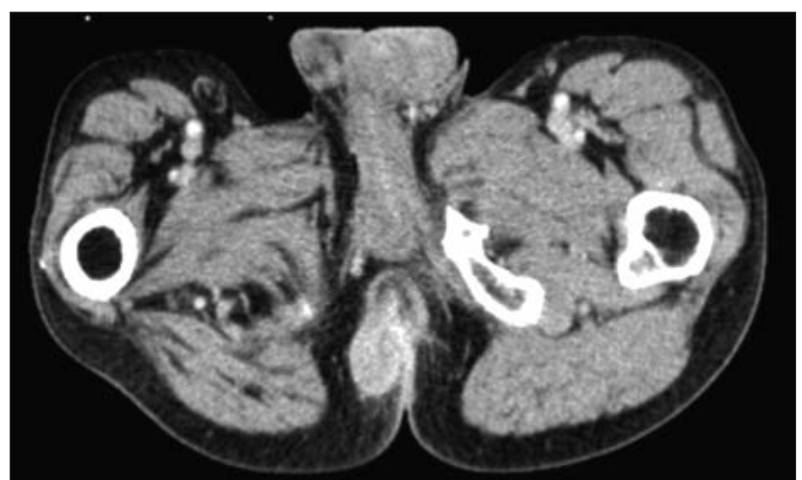

Figure 2. Rectal tumor on CT imaging

chemotherapy with Capecitabine $1000 \mathrm{mg} / \mathrm{m}^{2}$ twice daily, for 14 days, $\mathrm{q} 3 \mathrm{w}$.

Three weeks following the second cycle chemoradiotherapy was initiated.

Regarding radiotherapy, pelvic lymph nodes were irradiated to a total dose of 45 Gy, whilst for the rectum and perirectal tissue a boost of 5.4 Gy was administered up to a total dose of $50.4 \mathrm{~Gy}$, using a conventional 1.8 Gy fractionation scheme. Also, using the simultaneous-boost (SIB) technique the macroscopically invaded rectum portion was treated to a total dose of 56 Gy using a 2 Gy per fraction schedule. All treatments were administered in prone position, using a 7 field IMRT technique (Fig. 3). Verification images were performed weekly.

Concurrent Capecitabine chemotherapy was administered orally using a daily dose of $825 \mathrm{mg} / \mathrm{m}^{2}$, divided into two equal doses per day, including weekends.

Neoadjuvant treatment was well tolerated, as seen in Fig. 4, the patient presenting grade II-III radiodermatitis and grade II radiation enteritis.

The patient has been reevaluated 6 weeks after neoadjuvant therapy. At clinical exam, perianal region was tumor free, without ulcerative lesions or local induration; skin depigmentation postradiotherapy (Fig. 5). Digital rectal exam shows supple anal canal and rectal ampulla, without pathological modifications; good anal sphincter tone confirmed by manometry.

Colonoscopy finds normal mucosa from 

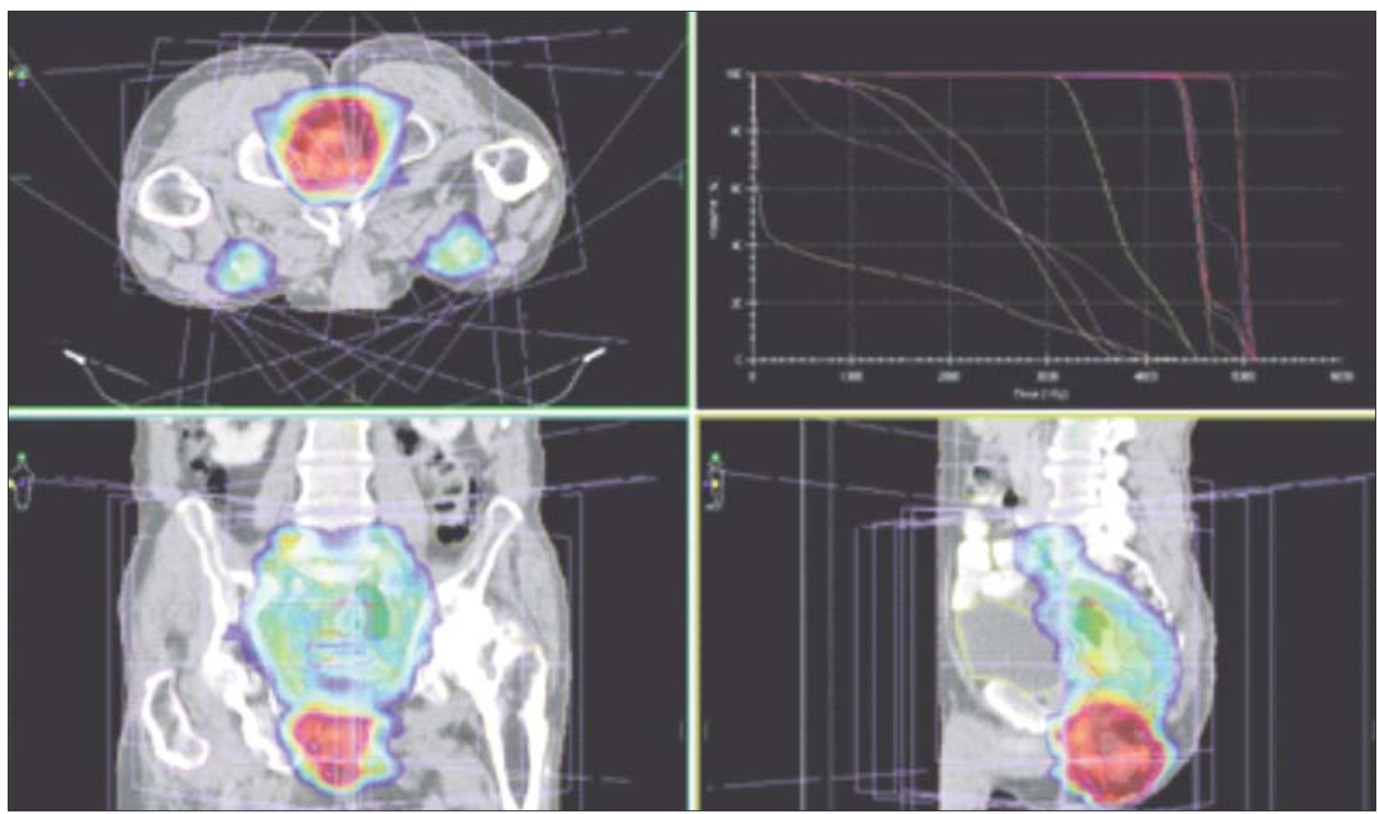

Figure 3. Dose distribution and beam arrangements (7 field IMRT treatment plan)

pectinate line to $7 \mathrm{~cm}$; between 7 and $10 \mathrm{~cm}$ circular schrinking of the lumena through parietal ulcerative lesions (remnant rectal tumor, infiltrative ulcerative form) - biopsies are taken (Fig. 6). Biopsy fragments, one with granulation tissue aspect with moderate polymorf inflammatory infiltrate (lymphocytes, plasmocytes, neutrophils); the other one with colonic mucosa aspect, with erosive areas, surface fibrinoleukocytic exsudate, including limited area of cells with tahichromazy and minimal nuclear hypertrophy,

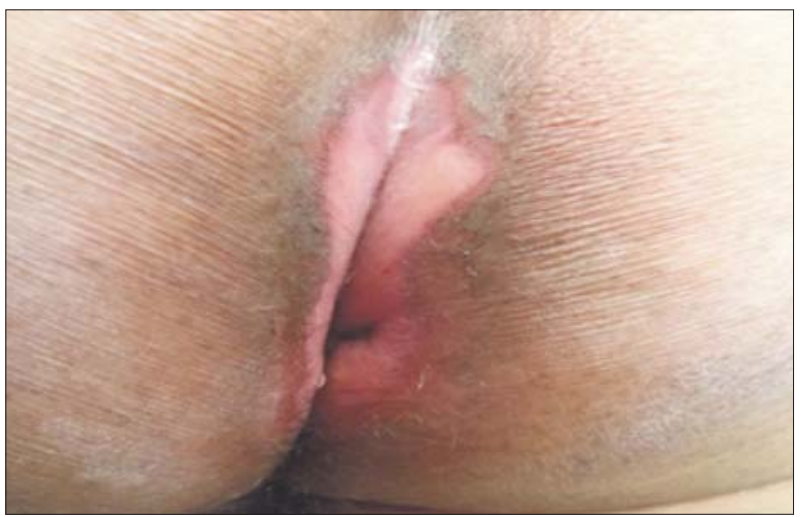

Figure 4. Perianal skin toxicity at the end of neoadjuvant chemoradiotherapy the histopahological diagnosis being small atypical cell group.

MRI scan reassessment shows iodophile irregular rectal thickening, located at superior and medium rectum, about $5 \mathrm{~cm}$ length - to be correlated with colonoscopy data. The described lesion associates discrete densfication of perilesional fat and satellite lymph nodes, maximum

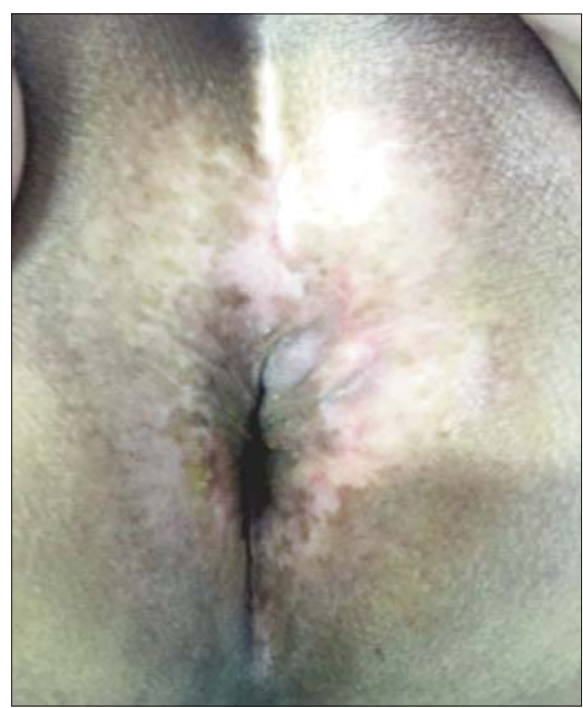

Figure 5. Perinal preoperative aspect 
Figure 6. Colonoscopy images after neoadjuvant therapy

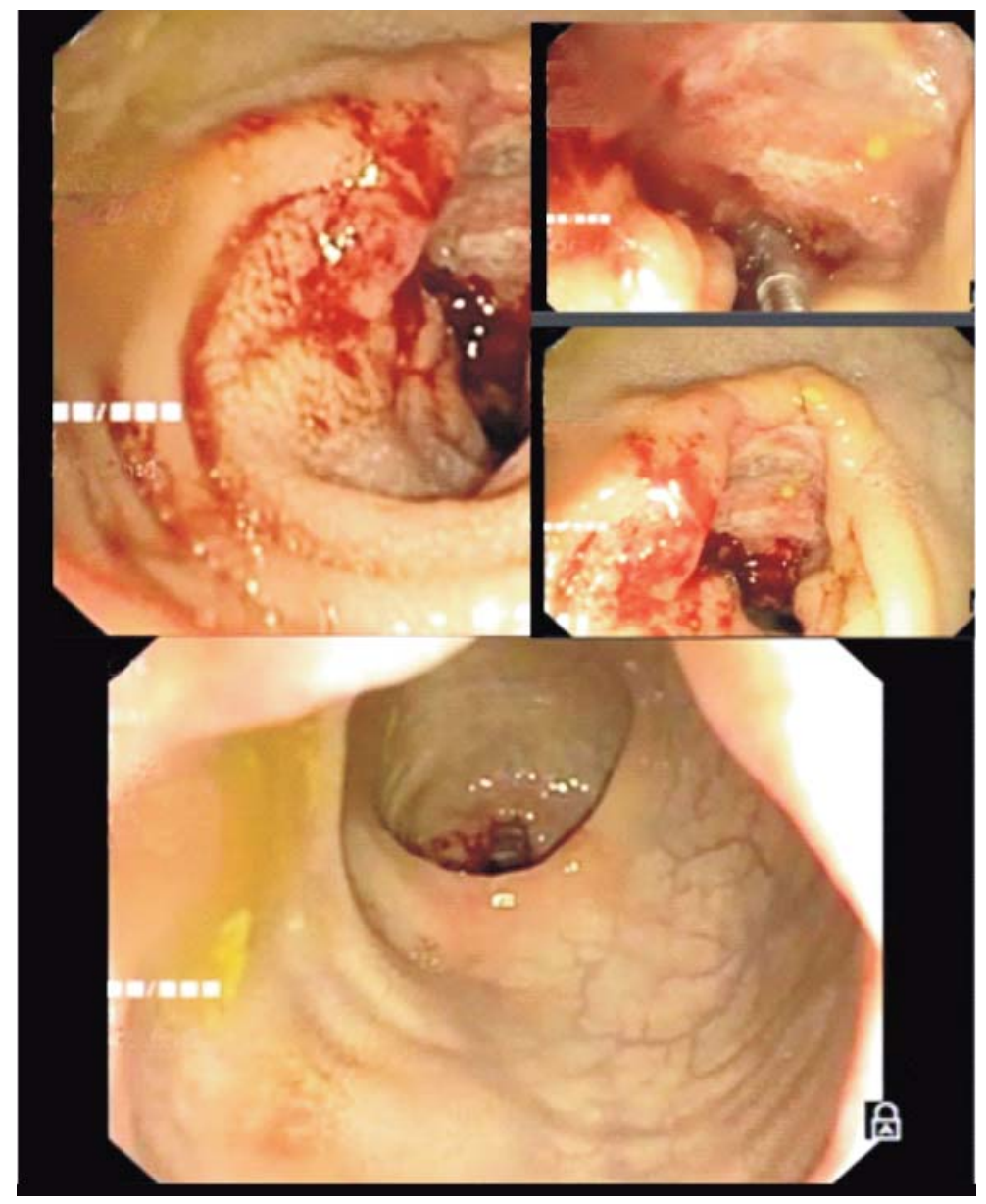

10/8 mm; no hepatic metastases found on CT.

After reassessment, complete remission of inferior rectal tumor and infiltrative ulcerative remnant tumor located in medium rectum, imagistic corresponding to a $5 \mathrm{~cm}$ in length, circular irregular thickening area are found.

The patient is guided to surgical department to perform the surgical terapheutical sequence. For personal reasons, he temporises this moment, surpassing the optimal recommended period to perform surgery after radiotherapy, 6 to 8 weeks. The surgical team presents the patient the surgical options, abdomino-perineal resection being the best solution with the lowest risk of recurrence in accordance to current guides. The patient delays one more time surgery, asking for thinking time. He firmly refuses colostomy, assuming recurrence risks and asks for a surgical procedure with anastomosis. After preoperative preparation, the surgical procedure is performed. Intraoperative, no important fibrosis modifications after radiotherapy are observed, no hepatic or peritoneal metastases are found. TME low rectal resection with colorectal mechanical anastomosis is performed (Fig. 7). A derivative protection ileostomy is done. Postoperative evolution is favorable.

\section{Histopathological result}

Adenocarcinoma remnant lesions with tubular and cribriform pattern, with mucosal ulceration areas, little necrosis areas, discrete desmoplastic reaction and polymorf inflammatory infiltrate, tumoral areas being present at mucosal, submucosal and muscular levels. 9 lymph nodes were examined - reactive aspect. ypT2pN0pMx. 


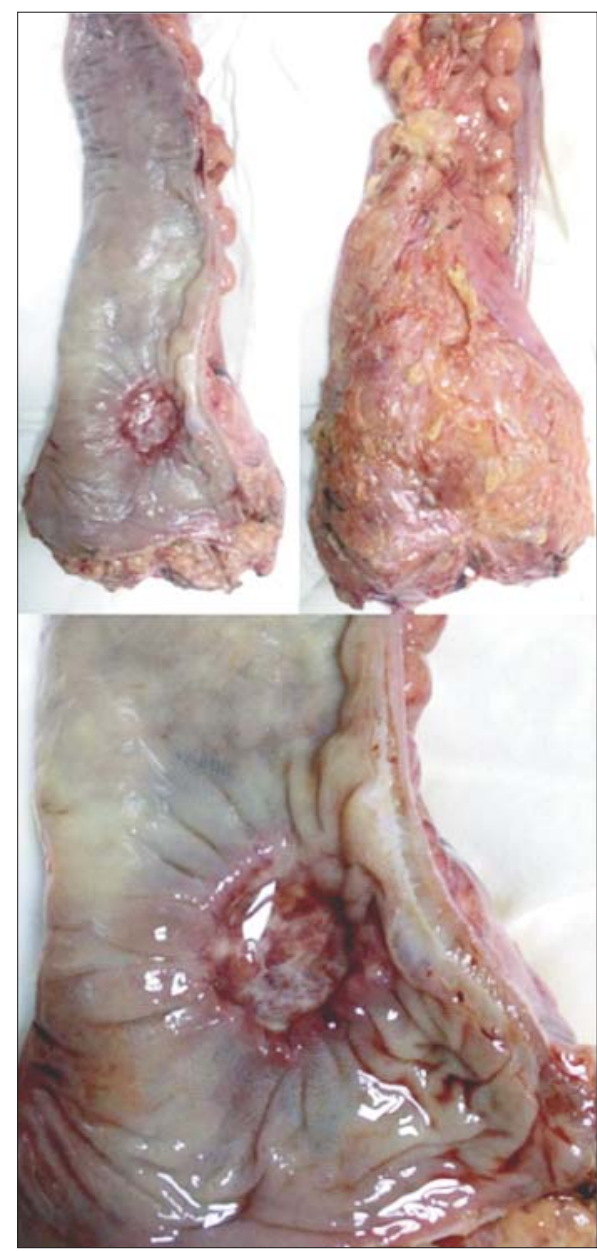

Figure 7. Surgical specimen with infiltrative ulcerative remnant tumor in medium rectum

Follow up proposed: clinical exam, serum CEA and colonoscopy/rectoscopy every 3 months in the first year, afterwards every 6 months and thorax and abdomen CT and pelvis MRI every 6 months in the first year, afterwards every year.

\section{Discussions}

The diagnosis particularity of the presented case is represented by the concomitant founding of two rectal tumours. It has been estimated that synchronous colorectal cancer represents $1.1-8.1 \%$ of all newly diagnosed colorectal cancers and some studies sustain the hypothesis that an environmental rather than a genetic component is involved, in which various etiologic factors might modify tumor progression, if we exclude hereditary forms of cancer such as Lynch syndrome or familial adenomatous polyposis (6). In this particular case, both tumors are strictly located at rectal level, the situation being statistically rare.

We cannot exclude the issue of the inferior rectal/anal tumor being a metastasis of primary superior/medium rectal tumor. The anal metastases are very rare, being reported in $0.7 \%$ cases of primary colorectal cancers (7). Although locally advanced rectal cancer is frequently associated with hematogenous dissemination, especially hepatic through portal vein, in the presented case were not reported distant metastases. It has been described the metastatic spread of colorectal cancer to a site in the perianal region, many reports documenting the implantation metastasis of rectal cancer in anal fistulas, after treatment of hemorrhoids or after colorectal surgery (8-12). Actually, exfoliated cancer cells were often observed in proximal and especially in distal colon in different studies (13). Some reports documented anal metastases through venous or lymphovascular dissemination $(14,15)$.

On the other hand, primary anal tumours are mostly squamous cell carcinoma, with adenocarcinoma accounting for $10 \%$ of all anal cancers (16). Carcinoma associated with fistula-in-ano is one example of primary tumor, adenocarcinoma arising in the anal ducts which are tubular structures originating at the base of the crypts (17).

Our present case had no documented history of fistula-in-ano, colorectal surgery, or anal surgery. The diagnosis started at clinical examination, a rough perianal tumor, corresponding to an endoanal lesion at digital rectal examination being found. Histopathological report showed intestinal adenocarcinoma. The colonoscopy revealed another voluminous medium rectal tumor. The distal tumor site between inferior rectum/anal canal, tumors dimensions, perianal region invasion, adenocarcinoma histopayhologic finding of the distal tumor biopsy and the lack of biopsy from the proximal tumor makes difficult the differential 
diagnosis between a primary or metastatic distal tumor. After a careful retrospective anamnesis we cannot exclude the possibility of a perianal fistula antecedents, the patient mentioning the evolution of a perianal small lesion not taken seriously into consideration.

Regarding radiotherapy, our option to use the SIB treatment technique was based on previous clinical data from the literature that confirmed the association of this therapeutic approach with high local control and low toxicity rates for locally advanced rectal cancer patients $(18,19)$. Due to the large target volumes, probably a similar target volume dose distribution would have been achieved by using 3D conformal radiotherapy (3D-CRT). However, recent dosimetric comparative data suggest that SIB treatment planning was associated with less gastrointestinal, skin and hematological toxicity when it was used with highly conformal radiotherapy techniques, such as IMRT, compared to 3D-CRT (20).

Also, in order to reduce the bowel volume exposed to a high radiaton dose the patient was treated in a prone position. Most literature data suggest that this position is better in terms of small bowel dose sparing $(21,22)$, although in the absence of a belly board, this advantage is reduced.

Reassessment after neoadjuvant therapy, a very important part of rectal cancer management, is many times omitted, surgical recommendations being made on initial staging. In our case, complete clinical remission (cCR) has been taken into consideration, at least for the distal rectal tumor. Regarding the proximal tumor, post therapeutical colonoscopy describes a circular schrinked lumen through ulcerative lesions, biopsies being negative. Characteristics like mucosa whitening or teleangiectasia suggest o complete remission, whilst stenosis, ulceration or palpable nodule at tumor site indicate an incomplete response and the necessity of surgery (23).

In a Dutch series where a "watch and wait" approach was adopted, cCR was defined by clinical absence of palpable or visible disease, the absence of suspicious lymph nodes at MRI, no disease or a small scar or ulcer at endoscopy and negative biopsies from the scar (24). Currently, it seems that there is no widespread consensus amongst colorectal surgeons as to the definition of a cCR (25).

Patients with no residual disease (cCR) or mural evidence of cancer at pathology report (ypT0) can harbour cancer cells within lymph nodes (26). On the other hand, some patients with residual clinical disease have achieved pathological complete response (pCR) (27). Clinical, endoscopic or imagistic prediction of pCR remains an important step for the future.

Another particularity of this case is the big interval of time between finalising neoadjuvant therapy and surgical procedure, due to patients reticence to perform surgery. The standard interval of time between radiochemotherapy and surgery is 6 to 8 weeks. Recent data indicate higher rates of pCR if this interval overpasses 8 weeks (28). In the analysed case, consequences of radiotherapy or big interval of time through surgery were not noticed intraoperative.

Therapeutical decision of surgical sequence was imposed by patient's categorical decline of colostomy and sustained by tumoral response to chemoradiotion. The distal tumor obtained complete remission and the approach was towards "wait and see", meanwhile the proximal tumor was submitted to radical surgery, on the specimen adenocarcinoma remnant lesions being found. Intershincteric proctocolectomy, another possible option in this particular case was excluded because of its contraindications - the initial external anal sphincter invasion [29] and the presence of T4, undifferentiated lesion [30].

\section{Conclusions}

The presented case is particular considering the diagnosis, two rectal tumors being found in the same time, and also regarding the therapeutical approach. Although, a radical abdomino-perineal resection would have been indicated, the patient's option to decline the colostomy imposed a radical intervention just for the proximal tumor. The inferior rectal tumour, with complete remission after neo- 
adjuvant therapy was submitted to "wait and see" approach.

\section{Conflict of interest}

All authors declare that they have no conflict of interest.

\section{Compliance with ethical standards}

All procedure followed have been performed in accordance with the ethical standards laid down in the 1964 Declaration of Helsinki and its later amendments.

Informed consent was obtained from all patients for being included in the study.

\section{References}

1. Pătrașcu T, Doran H, Mihalache 0 . Preoperative radiotherapy in rectal cancer treatment -- is it really a gold standard? Chirurgia (Bucur). 2014;109(2):185-90.

2. Chan AK, Wong A, Jenken D, Heine J, Buie D, Johnson D. Post treatment TNM staging is a prognostic indicator of survival and recurrence in tethered or fixed rectal carcinoma after preoperative chemotherapy and radiotherapy. Int J Radiat Oncol Biol Phys. 2005;61:665-77.

3. de Campos-Lobato LF, Stocchi L, da Luz MA, et al. Pathologic complete response after neoadjuvant treat- ment for rectal cancer decreases distant recurrence and could eradicate local recurrence. Ann Surg Oncol. 2011;18:1590-8.

4. Baker B, Salameh H, Al-Salman M, Daoud F. How does preoperative radiotherapy affect the rate of sphincter-sparing surgery in rectal cancer? Surg Oncol. 2012;21(3):e103-9.

5. Wynn GR, Bhasin N, Macklin CP, George ML. Complete clinical response to neoadjuvant chemora- diotherapy in patients with rectal cancer: opinions of British and Irish specialists. Colorectal Dis. 2010; 12(4):327-33.

6. Arriba M, Sánchez R, Rueda D, Gómez L, García JL, Rodríguez Y, Pajares JA, Pérez J, Urioste M, Sarmiento RG, Perea J. Toward a Molecular Classification of Synchronous Colorectal Cancer: Clinical and Molecular Characterization. Clin Colorectal Cancer. 2016. pii: S1533-0028(16)30121-9. doi: 10.1016/j.clcc.2016.07.014.

7. Takahashi H, Ikeda M, Takemasa I, et al. Anal metastasis of colorectal carcinoma origin: implications for diagnosis and treatment strategy. Dis Colon Rectum. 2011;54:472-81.

8. Killingback M, Wilson E, Hughes ES. Anal metastases from carcinoma of the rectum and colon. Aust NZ J Surg. 1965;34:178-87.

9. Isbister WH. Unusual 'recurrence' sites for colorectal cancer. Dig Surg. 2000:17:81-3.

10. Gupta R, Kay M, Birch DW. Implantation metastasis from adenocarcinoma of the colon into a fistula-in-ano: a case report. Can J Surg. 2005:48:162-3.

11. Hamada M, Ozaki K, Iwata J, Nishioka Y, Horimi T. A case of rectosigmoid cancer metastasizing to a fistula in ano. Jpn J Clin Oncol. 2005;35(11):676-9. Epub 2005 Nov 7.

12. Wind $\mathrm{P}$, Douard $\mathrm{R}$, Poupardin $\mathrm{E}$, Cugnenc $\mathrm{PH}$. Anal implantation of exfoliated tumour cells from a rectal adenocarcinoma after colorectal stapled anastomosis. Eur J Surg. 1999;165(9):905-6.
13. Umpleby HC, Fermor B, Symes MO, Williamson RC. Viability of exfoliated colorectal carcinoma cells. Br J Surg. 1984;71(9):659-63.

14. Kawanishi T, Sakaguchi M, Sekikawa T, Kishida Y, Yakumaru K. A case of rectal cancer with atypical spread. Syujyutsu. 2004;58: 1923-6.

15. Nishikawa T, Ishihara S, Ushiku T, Hata K, Sasaki K, Murono K, et al. Anal metastasis from rectal adenocarcinoma. Clin J Gastroenterol. 2016:9(6):379-383. Epub 2016 Oct 1.

16. Anwar S, Welbourn H, Hill J, Sebag-Montefiore D. Adenocarcinoma of the anal canal - a systematic review. Colorectal Dis. 2013;15(12): 1481-8. doi: 10.1111/codi.12325.

17. Mcintyre JM. Carcinoma associated with fistula-in-ano. Am J Surg. 1952;84:601-13.

18. Ballonoff A, Kavanagh B, McCarter M. Preoperative capecitabine and, accelerated intensity-modulated radiotherapy in locally advanced rectal cancer: a phase II trial. Am J Clin Oncol Cancer Clin Trials. 2008;31(3:264-70.

19. Garofalo M, Moughan J, Hong T, Bendell J, Berger A, Lerma F, et al. A Phase II Study of Preoperative (PREOP) Chemoradiotherapy (CRT) Utilizing IMRT in Combination with Capecitabine (C) and Oxaliplatin (0) for Patients with Locally Advanced Rectal Cancer. International Journal of Radiation Oncology, Biology, Physics. 2011;81(2):S3-S4.

20. Thawani N, Shilpa V, Hasan S, Axelrud G, Niloyjyoti D, Mutyala S. Effect of intensity-modulated radiation therapy with SIB technique on local control and toxicity for neoadjuvant pelvic radiation with concurrent 5-fluorouracil based chemotherapy for rectal cancer compared with three-dimensional conformal radiation therapies. J Clin Oncol. 2014; 32:Suppl 3:abstr 632.

21. Drzymala M, Hawkins MA, Henrys AJ, Bedford J, Norman A, Tait DM. The effect of treatment position, prone or supine, on dose-volume histograms for pelvic radiotherapy in patients with rectal cancer., The British journal of radiology. 2009;82(976):321-7

22. Surendra V, Moseley D, Chan E. Supine vs. Prone: A Retrospective Study on Rectum Patient Positioning. Journal of Medical Imaging and Radiation Sciences. 2014;45(2):177-78.

23. Perez R0, Habr-Gama A, Pereira GV, Lynn PB, Alves PA, Proscurshim I, et al. Role of biopsies in patients with residual rectal cancer following neoadjuvant chemoradiation after downsizing: can they rule out persisting cancer? Colorectal Dis. 2012;14(6):714-20.

24. Maas M1, Beets-Tan RG, Lambregts DM, Lammering G, Nelemans PJ, Engelen SM, et al. Wait-and-see policy for clinical complete responders after chemoradiation for rectal cancer. J Clin Oncol. 2011; 29(35):4633-40. doi: 10.1200/JC0.2011.37.7176. Epub 2011 Nov 7.

25. Wynn GR, Bhasin N, Macklin CP, George ML. Complete clinical response to neoadjuvant chemora- diotherapy in patients with rectal cancer: opinions of British and Irish specialists. Colorectal Dis. 2010; 12(4):327-33.

26. Bedrosian I, Rodriguez-Bigas MA, Feig B, Hunt KK, Ellis L, Curley SA, et al. Predicting the node-negative mesorectum after preoperative chemoradiation for locally advanced rectal carcinoma. J Gastrointest Surg. 2004;8(1):56-62; discussion 62-3.

27 Habr-Gama A, de Souza PM, Ribeiro U, Nadalin W, GansI R, Sousa Jr $\mathrm{AH}$, et al. Low rectal cancer: impact of radiation and chemotherapy on surgical treatment. Dis Colon Rectum. 1998;41:1087-96.

28. Kalady MF, de Campos-Lobato LF, Stocchi L, Geisler DP, Dietz D, Lavery IC, et al. Predictive factors of pathologic complete response after neoadjuvant chemoradiation for rectal cancer. Ann Surg. 2009; 250(4):582-9.

29. Martin ST, Heneghan HM, Winter DC. Systematic review of outcomes after intersphincteric resection for low rectal cancer. Br J Surg. 2012; 99(5):603-12. doi: 10.1002/bjs.8677. Epub 2012 Jan 13.

30. Schiessel R, Karner-Hanusch J, Herbst F, Teleky B, Wunderlich M. Intersphincteric resection for low rectal tumours. Br J Surg. 1994; 81(9):1376-8. 